\title{
Trends and socioeconomic differences in policy triggers for thinking about quitting smoking: Findings from the International Tobacco Control (ITC) Europe Surveys
}

Citation for published version (APA):

Hummel, K., Nagelhout, G. E., Willemsen, M. C., Driezen, P., Springvloet, L., Mons, U., Kunst, A. E., Guignard, R., Allwright, S., van den Putte, B., Hoving, C., Fong, G. T., McNeill, A., Siahpush, M., \& de Vries, $H$. (2015). Trends and socioeconomic differences in policy triggers for thinking about quitting smoking: Findings from the International Tobacco Control (ITC) Europe Surveys. Drug and Alcohol Dependence, 155, 154-162. https://doi.org/10.1016/j.drugalcdep.2015.07.678

Document status and date:

Published: 01/10/2015

DOI:

10.1016/j.drugalcdep.2015.07.678

Document Version:

Publisher's PDF, also known as Version of record

Document license:

Taverne

Please check the document version of this publication:

- A submitted manuscript is the version of the article upon submission and before peer-review. There can be important differences between the submitted version and the official published version of record. People interested in the research are advised to contact the author for the final version of the publication, or visit the DOI to the publisher's website.

- The final author version and the galley proof are versions of the publication after peer review.

- The final published version features the final layout of the paper including the volume, issue and page numbers.

Link to publication

\footnotetext{
General rights rights.

- You may freely distribute the URL identifying the publication in the public portal. please follow below link for the End User Agreement:

www.umlib.nl/taverne-license

Take down policy

If you believe that this document breaches copyright please contact us at:

repository@maastrichtuniversity.nl

providing details and we will investigate your claim.
}

Copyright and moral rights for the publications made accessible in the public portal are retained by the authors and/or other copyright owners and it is a condition of accessing publications that users recognise and abide by the legal requirements associated with these

- Users may download and print one copy of any publication from the public portal for the purpose of private study or research.

- You may not further distribute the material or use it for any profit-making activity or commercial gain

If the publication is distributed under the terms of Article 25fa of the Dutch Copyright Act, indicated by the "Taverne" license above, 


\title{
Trends and socioeconomic differences in policy triggers for thinking about quitting smoking: Findings from the International Tobacco Control (ITC) Europe Surveys
}

\author{
Karin Hummel ${ }^{\mathrm{a}, *}$, Gera E. Nagelhout ${ }^{\mathrm{a}, \mathrm{b}}$, Marc C. Willemsen ${ }^{\mathrm{a}, \mathrm{b}}$, Pete Driezen ${ }^{\mathrm{c}}$, \\ Linda Springvloet $^{\mathrm{a}}$, Ute Mons ${ }^{\mathrm{d}, \mathrm{e}}$, Anton E. Kunst ${ }^{\mathrm{f}}$, Romain Guignard ${ }^{\mathrm{g}}$, Shane Allwright ${ }^{\mathrm{h}}$, \\ Bas van den Putte ${ }^{i, j}$, Ciska Hoving ${ }^{a}$, Geoffrey T. Fong ${ }^{c, k}$, Ann McNeill ${ }^{1}$, \\ Mohammad Siahpush ${ }^{\mathrm{m}}$, Hein de Vries ${ }^{\mathrm{a}}$ \\ a Department of Health Promotion, Maastricht University (CAPHRI), Maastricht, The Netherlands \\ ${ }^{\mathrm{b}}$ Dutch Alliance for a Smokefree Society, The Hague, The Netherlands \\ ${ }^{\mathrm{c}}$ Department of Psychology, University of Waterloo, Waterloo, ON, Canada \\ d Division of Clinical Epidemiology and Aging Research, German Cancer Research Center (DKFZ), Heidelberg, Germany \\ e Unit Cancer Prevention, German Cancer Research Center (DKFZ), Heidelberg, Germany \\ ${ }^{\mathrm{f}}$ Department of Public Health, Academic Medical Centre, University of Amsterdam, Amsterdam, The Netherlands \\ ${ }^{g}$ Scientific Affairs Department, National Institute for Health Promotion and Health Education (INPES), Saint-Denis, France \\ h Department of Public Health and Primary Care, Trinity College Dublin, University of Dublin, Dublin, Republic of Ireland \\ ${ }^{i}$ Department of Communication, University of Amsterdam (ASCOR), Amsterdam, The Netherlands \\ ${ }^{\mathrm{j}}$ Trimbos Institute, Netherlands Institute for Mental Health and Addiction, Utrecht, The Netherlands \\ k Ontario Institute for Cancer Research, Toronto, ON, Canada \\ ${ }^{1}$ King's College London, Institute of Psychiatry, Psychology and Neuroscience, UK Centre for Tobacco and Alcohol Studies, London, UK \\ m Department of Health Promotion, College of Public Health, University of Nebraska Medical Center, Omaha, NE, USA
}

\section{A R T I C L E I N F O}

\section{Article history:}

Received 18 March 2015

Received in revised form 7 July 2015

Accepted 25 July 2015

Available online 31 July 2015

\section{Keywords:}

Cessation

Socioeconomic status

Public policy

\begin{abstract}
A B S T R A C T
Introduction: The aim of the current study is to investigate trends and socioeconomic differences in policy triggers for thinking about quitting in six European countries.

Methods: Data were derived from all available survey waves of the International Tobacco Control (ITC) Europe Surveys (2003-2013). France conducted three survey waves $(n=1420-1735)$, Germany three waves $(n=515-1515)$, The Netherlands seven waves $(n=1420-1668)$, Ireland three waves ( $n=582-1071)$, Scotland two waves $(n=461-507)$, and the rest of the United Kingdom conducted seven survey waves ( $n=861-1737)$. Smokers were asked whether four different policies (cigarette price, smoking restrictions in public places, free or lower cost medication, and warning labels on cigarette packs) influenced them to think about quitting. Generalized Estimating Equation (GEE) models were estimated for each country.

Results: Cigarette price was mentioned most often in all countries and across all waves as trigger for thinking about quitting. Mentioning cigarette price and warning labels increased after the implementation of price increases and warning labels in some countries, while mentioning smoking restrictions decreased after their implementation in four countries. All studied policy triggers were mentioned more often by smokers with low and/or moderate education and income than smokers with high education and income. The education and income differences did not change significantly over time for most policies and in most countries.

Conclusions: Tobacco control policies work as a trigger to increase thoughts about quitting, particularly in smokers with low education and low income and therefore have the potential to reduce health inequalities in smoking.
\end{abstract}

(c) 2015 Elsevier Ireland Ltd. All rights reserved.

\footnotetext{
* Corresponding author. Present address: P. Debyeplein 1, 6229 HA, Maastricht, The Netherlands. Tel.: +31 433882400.

E-mail address: Karin.Hummel@maastrichtuniversity.nl (K. Hummel).
} 


\section{Introduction}

Despite the implementation of multiple tobacco control policies and smoking cessation interventions in many countries, tobacco use remains the number one preventable cause of death and disease (WHO, 2012). Increasingly, the burden of tobacco use has become concentrated within low socioeconomic status (SES) groups (Giskes et al., 2005; Harper and Lynch, 2007; Hiscock et al., 2012; Hosseinpoor et al., 2012), and tobacco use has been found to account for a considerable proportion of the health inequalities as a function of SES. Thus, it is becoming increasingly important to understand what factors trigger quitting among low SES smokers to inform public health policies and programs that could increase quitting among those population groups for whom quitting is considerably more difficult (Hiscock et al., 2012).

Research has confirmed the basic theoretical notion that thinking about quitting is an essential prerequisite for attempting to quit (Caleyachetty et al., 2012; Fong et al., 2006). Specific environmental cues can be beneficial to trigger people's intentions to change their behavior, as described for example in the Health Belief Model (Rosenstock, 1974), Reasoned Action Approach (Fishbein and Ajzen, 2010), Social Cognitive Theory (Bandura, 1986), and Protection Motivation Theory (Rogers and Prentice-Dunn, 1997). A policy or change in policy could be such a trigger. For example, the implementation of smoking restrictions in public places can be a trigger for smokers to re-evaluate their smoking behavior (Hammond et al., 2004). If these policy triggers are weaker for low SES smokers in stimulating quitting, such policies may widen SES differences.

Several studies have identified the reasons smokers cite for quitting smoking. The most frequently mentioned reason is concern for one's current as well as future health (Baha and Le Faou, 2010; Gallus et al., 2013; Grotvedt and Stavem, 2005; Kaleta et al., 2012; McCaul et al., 2006; Pisinger et al., 2011; Vangeli and West, 2008). Other reasons include social pressure, children, disliking being addicted, improving physical fitness, and financial costs. Some studies also investigated income or education differences regarding these reasons (Grotvedt and Stavem, 2005; Pisinger et al., 2011; Vangeli and West, 2008). These studies generally conclude that low SES smokers are more likely than high SES smokers to quit smoking because of the costs and because of current health-related reasons. Smokers with high income are more likely to quit smoking because they dislike being addicted.

There have been few studies on income and education differences regarding policy triggers that influence thinking about quitting smoking. One study conducted in England tested whether there existed SES differences in mentioning various triggers for quitting (Vangeli and West, 2008). For smoking restrictions, no SES differences were found; in contrast, warning labels and financial costs were more often mentioned by low SES groups. Another study found that after the implementation of workplace smoking restrictions in France, smoking restrictions were mentioned more frequently by employed than unemployed smokers as motive for wanting to quit, but in general this reason was reported quite rarely (Baha and Le Faou, 2010). However, these studies were conducted at only one measurement point in time and only in one country. Therefore, it is unknown whether mentioning policy triggers for quitting and socioeconomic differences change after the implementation of policies.

The aim of the current study was to investigate trends and socioeconomic differences in policy triggers for thinking about quitting in six European countries: France, Germany, The Netherlands, Ireland, Scotland, and the rest of the United Kingdom (UK). These countries have ratified the WHO Framework Convention on Tobacco Control (FCTC) (WHO, 2003). Furthermore, they implemented cigarette price increases, smoking restrictions in public places, reimbursement of cessation medication, and warning labels, although the specific regulations vary.

An overview of the implementation dates of policies in the included countries is shown in Fig. 1. The timing and magnitude of retail cigarette price changes varied between countries (European Commission, 2014). We adjusted the retail cigarette prices for inflation in each country (The World Bank, 2015) and only included adjusted price increases of at least $5 \%$ because larger price increases were associated with more smokers reporting to consider quitting in previous research (Guillaumier et al., 2014; Scollo et al., 2013). Smoking restrictions in public places were implemented in all countries, but there were exceptions in some countries (e.g., in Germany smoking restrictions vary between federal states). All countries, except Germany, had at least some level of reimbursement for stop-smoking medication, but in The Netherlands, the reimbursement was introduced in 2011, discontinued in 2012, and reinstated in 2013. Finally, warning labels on cigarette packs were mandatory in the six countries; France implemented textual warning labels in 2003 and pictorial warning labels between 2010 and 2011 and thus changed the health warnings during the current study. Germany and The Netherlands implemented textual warning labels in 2003 and 2002, respectively, and had them throughout the whole study period. Ireland implemented textual warning labels in 2002 and pictorial warning labels in 2013. The UK (including Scotland) implemented textual warning labels in 2003 and pictorial warning labels between 2008 and 2010. The UK thus also changed the health warnings during the current study, but no Scottish data from the time after the implementation were available.

With data from the International Tobacco Control (ITC) Europe Surveys, we examined trends in self-reported triggers for as many as seven yearly waves in some countries. The following research questions were addressed: (1) Do self-reported triggers for thinking about quitting change over time?, (2) Are there education and income differences regarding reporting these triggers?, and (3) Do these education and income differences change over time?

\section{Methods}

\subsection{Design and samples}

Data from the ITC Surveys in six European countries were analyzed: France, Germany, The Netherlands, Ireland, Scotland, and the rest of the UK. The ITC Surveys follow a longitudinal cohort design. The countries varied with respect to the number of survey waves and the time interval between survey waves (Fig. 1). The study period ranged from 2003 until 2013. As in all countries participating in ITC, respondents in the ITC Europe Surveys who were lost to attrition were replenished by recruiting new respondents from the same sampling frame to the cohort at every survey wave, except for Germany wave 2 and 3, Ireland wave 3, and UK wave 8 where replenishment was not possible due to funding constraints. Drop-out between the first and the last included wave ranged across countries between 35\% in Scotland (two waves) and $88.5 \%$ in the UK (seven waves). In all countries, younger smokers were more likely to drop out of the sample and in France and Scotland smokers with low education. In each of the six countries, the sampling was at the national level. For the current study, smokers of 18 years and older in each wave were included in the analyses. Smokers were defined as respondents who smoked at least 100 cigarettes in their lifetime and were currently smoking cigarettes at least monthly. More details about the specific methods and the theoretical framework of the ITC Project are published elsewhere (Fong et al., 2006; The International Tobacco Control Evaluation Project, 2014; Thompson et al., 2006).

For the current study, all available survey waves of all ITC Europe countries were used, with two exceptions. Wave 2 of The Netherlands Survey was excluded because this was a 'subwave' in-between the yearly survey waves with a smaller sample size. Wave 1 of the UK Survey was excluded because the outcome variables were not yet measured in that wave; Scottish data were excluded from all the UK waves. The number of studied survey waves ranged between two (Scotland) and seven (UK) per country. Also, sample sizes varied between countries and survey waves (1420-1735 in France; 515-1515 in Germany; 1393-1668 in The Netherlands; 582-1071 in Ireland; 461-507 in Scotland; 861-1737 in the UK). All countries surveyed respondents via the telephone except for The Netherlands, where the internet was used. 


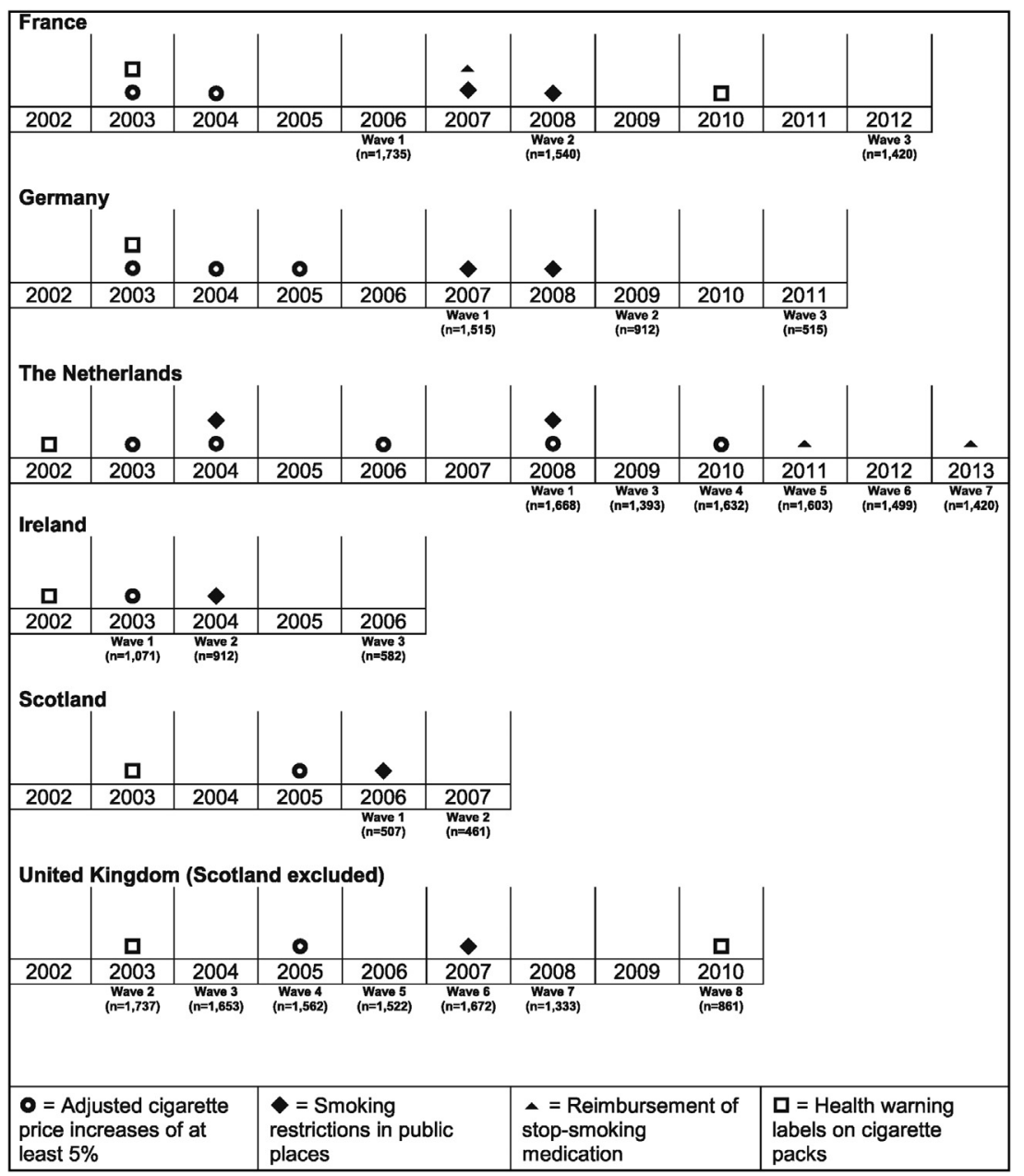

Fig. 1. Timeline of changes in tobacco control policies in the six countries, including timing of the survey waves and number of respondents.

\subsection{Measurements}

Smokers were asked whether four different policies led them to think about quitting: 'In the past 6 months, have each of the following things led you to think about quitting?' (1) The price of cigarettes, (2) Smoking restrictions in public places like restaurants, cafes and pubs, (3) Free, or lower cost, stop-smoking medication, (4) Warning labels on cigarette packages. Response options were: not at all, somewhat, very much. The answers were dichotomized into 'not at all' (0) and 'somewhat' and 'very much' (1).

Furthermore, respondents were asked about their level of completed education and their income. Due to differences in educational systems across the six countries, the measures of completed education were only partially comparable. Completed education was categorized into low (none completed, elementary school and lower secondary education), moderate (secondary vocational education and middle secondary education), and high (upper secondary education, university and post-graduate). Respondents from The Netherlands, Ireland, Scotland, and the rest of the UK were asked about their monthly gross household income, while respondents from France and Germany reported their monthly net household income. The response options for the income question were not the same across the countries. Therefore, within each country, a three-level income variable was created: low, moderate, and high. This approximated an even distribution as closely as possible, which allowed comparisons to be made across countries. Respondents also had the opportunity to refuse to answer the income question or answer it with 'don't know'. This group was relatively small in most countries (Table 1). Sensitivity analyses with and without an extra category for respondents who did not answer the income question were performed for Germany and The Netherlands where this group was largest. This did not change the pattern of the results and therefore, this group was excluded from all reported analyses.

Other covariates were gender, age, and level of nicotine dependence. Age was categorized into: $18-24$ years, $25-39$ years, $40-54$ years, and 55 years and older. The Heaviness of Smoking Index (HSI) was used as indicator of level of nicotine dependence (Heatherton et al., 1989). This index is the sum of the categorized number of cigarettes smoked per day and the time to the first cigarette of the day.
The range of the HSI is from 0 to 6 , with a higher score indicating higher nicotine dependence.

\subsection{Analyses}

All analyses were conducted with SPSS version 20.0. In all analyses, sampling weights were computed based on gender and age and applied within each country. Pearson Chi-Square analyses were conducted for each country to assess statistical significance of changes in mentioning whether the four policies led smokers to think about quitting between each pair of two consecutive waves. We expected that the implementation of a policy would be followed by an increase of mentioning this policy as a trigger in the subsequent survey wave. Therefore, we calculated the percentage of increases when these were expected and compared this with the percentage of increases when these were not expected. The exact timing of the implementation of the policies and the timing of the survey waves (depicted schematically in Fig. 1) was used to determine the expectations (indicated with shadings in Table 2).

Furthermore, Generalized Estimating Equation (GEE) models were estimated for each country. Outcome measures in the GEE analyses were the dichotomized four policy triggers for thinking about quitting. Therefore, the binomial distribution and the logit link were used (Ballinger, 2004). The unstructured correlation structure was used because this structure is most valid for large samples (Jin, 2011). The repeated measure variable was survey wave, and the parameters of interest were income, education, and wave. All GEE analyses were adjusted for gender, age group at baseline, and HSI. Furthermore, we adjusted for respondents' number of survey waves (time in sample) because previous research has shown that survey responses can vary as a function of time in sample (Driezen and Thompson, 2011). Moreover, we included interaction terms on top of the main effects for income by survey wave and for education by survey wave in separate analyses to examine whether income and education differences changed over time. Every analysis was conducted for each country separately. Due to the relatively large number of comparisons being made, an alpha level for significant differences of $<0.01$ was chosen (Lang and Secic, 2006). 
Table 1

Sample characteristics of smokers at first included survey wave, by country (weighted data).

\begin{tabular}{|c|c|c|c|c|c|c|}
\hline & $\begin{array}{l}\text { France } \\
(2006) \\
n=1735\end{array}$ & $\begin{array}{l}\text { Germany } \\
(2007) \\
n=1515\end{array}$ & $\begin{array}{l}\text { The Netherlands } \\
(2008) \\
n=1668\end{array}$ & $\begin{array}{l}\text { Ireland } \\
(2003) \\
n=1071\end{array}$ & $\begin{array}{l}\text { Scotland } \\
(2006) \\
n=507\end{array}$ & $\begin{array}{l}\text { UK (Scotland } \\
\text { excluded) (2003) } \\
n=1737\end{array}$ \\
\hline \multicolumn{7}{|l|}{ Sex } \\
\hline Male (\%) & 55.7 & 57.7 & 54.3 & 51.3 & 54.3 & 49.0 \\
\hline \multicolumn{7}{|l|}{ Age group } \\
\hline $18-24$ years $(\%)$ & 17.5 & 13.7 & 11.5 & 20.2 & 11.5 & 15.2 \\
\hline $25-39$ years $(\%)$ & 35.6 & 31.0 & 29.3 & 36.2 & 25.5 & 31.8 \\
\hline $40-54$ years $(\%)$ & 32.5 & 36.1 & 34.8 & 25.7 & 33.1 & 29.9 \\
\hline 55 years and older (\%) & 14.4 & 19.1 & 24.5 & 17.9 & 29.9 & 23.1 \\
\hline \multicolumn{7}{|l|}{ Education } \\
\hline Low (\%) & 16.9 & 22.6 & 37.9 & 31.7 & 23.0 & 37.6 \\
\hline Moderate (\%) & 36.3 & 37.0 & 42.7 & 34.1 & 35.3 & 23.8 \\
\hline High (\%) & 46.8 & 40.5 & 19.4 & 34.1 & 41.7 & 38.5 \\
\hline \multicolumn{7}{|l|}{ Income } \\
\hline Low (\%) & 40.6 & 37.6 & 36.6 & 33.4 & 38.1 & 27.3 \\
\hline Moderate (\%) & 29.0 & 26.2 & 26.9 & 21.8 & 41.7 & 33.9 \\
\hline $\operatorname{High}(\%)$ & 27.0 & 22.4 & 14.9 & 35.9 & 11.7 & 31.7 \\
\hline Not reported (\%) & 3.4 & 13.9 & 21.6 & 8.9 & 8.5 & 7.0 \\
\hline
\end{tabular}

Sensitivity analyses (adjusted GEE analyses) concerning the association between mentioning a policy as trigger and making a quit attempt in the next year revealed acceptable associations. Mentioning cigarette price was significantly associated with quit attempts in all countries except for the UK (including Scotland). Mentioning smoking restrictions was associated with quit attempts in The Netherlands, Ireland and the UK (excluding Scotland). Mentioning free or lower cost medication was associated with quit attempts in all countries except for Ireland and Scotland. Mentioning warning labels was associated with quit attempts in all countries except for France, The Netherlands and Scotland.

Table 2

Percentages of smokers who answered 'yes' to the question whether a certain policy would lead them to think about quitting (weighted data) ${ }^{\text {a }}$

\begin{tabular}{|c|c|c|c|c|}
\hline & $\begin{array}{l}\text { Price of } \\
\text { cigarettes } \\
(\%)\end{array}$ & $\begin{array}{l}\text { Smoking } \\
\text { restrictions in } \\
\text { public places (\%) }\end{array}$ & $\begin{array}{l}\text { Free or } \\
\text { lower cost } \\
\text { medication (\%) }\end{array}$ & $\begin{array}{l}\text { Warning labels } \\
\text { on cigarette } \\
\text { packs (\%) }\end{array}$ \\
\hline \multicolumn{5}{|l|}{ France } \\
\hline Wave $1(n=1735)$ & 61.8 & 35.6 & Not measured & 33.9 \\
\hline Wave $2(n=1540)$ & 62.8 & $30.2^{*}$ & & 30.8 \\
\hline Wave $3(n=1420)$ & $76.1^{* *}$ & $23.6^{* *}$ & & 36.1 \\
\hline \multicolumn{5}{|l|}{ Germany } \\
\hline Wave $1(n=1515)$ & 72.3 & 39.4 & 21.8 & 27.9 \\
\hline Wave $2(n=912)$ & 70.9 & $30.3^{* * *}$ & $16.1^{* *}$ & 28.4 \\
\hline Wave $3(n=515)$ & 64.6 & 25.6 & 16.7 & 24.5 \\
\hline \multicolumn{5}{|l|}{ The Netherlands } \\
\hline Wave $1(n=1668)$ & 52.2 & 37.1 & 29.1 & 16.8 \\
\hline Wave $3(n=1393)$ & $57.1 *$ & $30.6^{* *}$ & $39.4^{* *}$ & 19.4 \\
\hline Wave $4(n=1632)$ & 52.1 & $25.4^{*}$ & $30.8^{* *}$ & 17.5 \\
\hline Wave $5(n=1603)$ & $61.5^{* *}$ & 25.6 & 34.5 & 17.7 \\
\hline Wave $6(n=1499)$ & 60.9 & 27.2 & 32.0 & 15.4 \\
\hline Wave $7(n=1420)$ & $67.0^{*}$ & 24.8 & 28.7 & 15.0 \\
\hline \multicolumn{5}{|l|}{ Ireland } \\
\hline Wave $1(n=1071)$ & 76.5 & 60.4 & 41.5 & 47.5 \\
\hline Wave $2(n=912)$ & 73.3 & 56.7 & 41.2 & 46.1 \\
\hline Wave $3(n=582)$ & 73.3 & 48.2 & $51.6^{* *}$ & 42.1 \\
\hline \multicolumn{5}{|l|}{ Scotland } \\
\hline Wave $1(n=507)$ & 69.7 & 53.3 & 49.0 & 39.7 \\
\hline Wave $2(n=461)$ & 71.5 & $42.5^{* *}$ & 46.2 & 39.0 \\
\hline \multicolumn{5}{|l|}{ UK (Scotland excluded) } \\
\hline Wave $2(n=1737)$ & 65.5 & 35.1 & 36.8 & 41.8 \\
\hline Wave $3(n=1653)$ & 69.1 & $41.4^{* *}$ & $44.4^{* *}$ & 38.3 \\
\hline Wave $4(n=1562)$ & 71.5 & $52.2^{* *}$ & $49.2^{*}$ & 37.9 \\
\hline Wave $5(n=1522)$ & 71.0 & 53.8 & 45.8 & 35.4 \\
\hline Wave $6(n=1672)$ & $65.0^{* *}$ & 51.5 & 42.5 & $30.1^{*}$ \\
\hline Wave $7(n=1333)$ & 62.4 & 49.1 & 39.0 & 33.8 \\
\hline Wave $8(n=861)$ & 65.2 & 45.8 & 42.6 & $40.9^{* *}$ \\
\hline $\mathrm{n}$ increases when expected & $2 / 4=50 \%$ & $0 / 6=0 \%$ & $0 / 2=0 \%$ & $2 / 2=100 \%$ \\
\hline $\mathrm{n}$ increases when not expected & $2 / 14=14 \%$ & $2 / 12=17 \%$ & $4 / 14=29 \%$ & $0 / 16=0 \%$ \\
\hline
\end{tabular}

a $p$-Values for Pearson Chi-Square tests of differences with the previous survey wave.

Shaded cells are cells in which increases are expected based on policy changes (as depicted in Fig. 1).

${ }^{*} p<0.01$.

** $p<0.001$ 


\subsection{Ethics}

The surveys were cleared for ethics by the Research Ethics Board of the University of Waterloo and by the appropriate institutions of each country when needed.

\section{Results}

\subsection{Sample description}

Table 1 shows the socio-demographic characteristics of smokers of the first wave that was included for each country (wave 2 for the UK, wave 1 for the other countries). The Netherlands and the UK (excluding Scotland) had the highest percentage of low education smokers. A greater percentage of German and Dutch smokers did not report their income.

\subsection{Most frequently reported triggers}

Table 2 shows the frequencies of smokers who reported that a specific policy was a trigger for them to think about quitting by country and wave. Mentioning cigarette price as trigger ranged on average from $59 \%$ in The Netherlands to $74 \%$ in Ireland. Mentioning smoking restrictions in public places ranged on average from $29 \%$ in The Netherlands to $55 \%$ in Ireland. Mentioning free or lower cost medication ranged on average from $18 \%$ in Germany to $48 \%$ in Scotland. Mentioning warning labels as a trigger for thinking about quitting ranged on average from $17 \%$ in The Netherlands to $45 \%$ in Ireland.

By far the most common reported policy trigger in all countries at all waves was cigarette price. The second most frequently reported policy trigger was free or lower cost of cessation medication in The Netherlands, Ireland, and Scotland, and smoking restrictions in public places in Germany and the rest of the UK. The least common policy trigger was warning labels on cigarette packs in all countries except in France, where it was the second most common trigger at wave 3 .

Shaded cells in Table 2 indicate where an increase was expected based on a change in a tobacco control measure (i.e., cigarette price increase, introduction or intensifying of smoking restrictions, free or lower cost medication, and warning labels). Across the four policy domains, the percentage of significant increases where these were expected was $29 \%$ ( 4 out of 14 ) while the percentage of significant increases where these were not expected was $14 \%$ ( 8 out of 56). Regarding smoking restrictions in public places, we found significant decreases in four countries when increases were expected.

\subsection{Changes in triggers over time}

Table 3 shows the results of the GEE analyses by country which examined income, education, and time (survey wave) differences in mentioning policy triggers for thinking about quitting. Price of cigarettes as a trigger for thinking about quitting increased significantly across survey waves in France $(\mathrm{OR}=1.24, p<0.001)$ and The Netherlands $(\mathrm{OR}=1.13, p<0.001)$, while no change across waves could be demonstrated in the other countries. Reporting smoking restrictions decreased in France $(\mathrm{OR}=0.72, p<0.001)$, Germany $(\mathrm{OR}=0.72, p<0.001)$, The Netherlands $(\mathrm{OR}=0.92, p<0.001)$, and Scotland $(\mathrm{OR}=0.66, p=0.005)$. No change could be demonstrated in Ireland and it increased in the UK $(\mathrm{OR}=1.14, p<0.001)$. There was no significant change across survey waves in mentioning free or lower cost medication as a trigger for thinking about quitting in any of the countries where this question was asked (it was not assessed in France). There was a significant decrease across waves in reporting warning labels on cigarette packs as a trigger for thinking about quitting in the UK $(\mathrm{OR}=0.95, p<0.001)$, but no change over time could be demonstrated in the other countries.

\subsection{Education and income differences}

As shown in Table 3, price of cigarettes was more often reported as a trigger for thinking about quitting by moderate education (compared to high education) smokers in Germany and Scotland, and more often by low and/or moderate income (compared to high income) smokers in France, Germany, The Netherlands, and Scotland. For the UK, the interaction between education and survey wave was significant $(p=0.004)$. Stratified analyses for the UK (not shown in tables) showed that reporting of price of cigarettes as a trigger for thinking about quitting increased across waves among high education smokers, while it decreased among moderate education smokers, but both associations were not significant.

Smoking restrictions in public places were more often mentioned by smokers with low education in Germany, and more often by smokers with low and moderate income in France. The interaction between education and survey wave was significant for Scotland $(p=0.009)$. Stratified analyses showed that the decrease in reporting of smoking restrictions as a trigger in Scotland was larger among high education smokers. Also, the interaction between income and survey wave was significant for reporting of smoking restrictions as a trigger for Scotland $(p=0.009)$ and the rest of the UK $(p=0.006)$. Stratified analyses showed that the decrease across waves was larger among moderate income smokers than high income smokers in Scotland, and that the increase was larger among high income smokers than among low and moderate income smokers in the UK.

Free or lower cost medication was reported more often by smokers with low and/or moderate education in Germany and The Netherlands, and more often by low and/or moderate income smokers in Germany, The Netherlands, Ireland, and the UK.

Warning labels on cigarette packs were mentioned more often by low education smokers in Scotland, and more often by low and/or moderate income smokers in France, The Netherlands, and Ireland. The interaction between education and survey wave was significant for France $(p=0.007)$. Stratified analyses showed that there was an increase in reporting of warning labels as a trigger for thinking about quitting among low education smokers in France, while no change could be demonstrated among smokers with moderate and high education.

\section{Discussion}

The aim of the current study was to examine trends and socioeconomic differences in reporting four policies as a trigger for thinking about quitting among smokers in six European countries. We found that cigarette price was mentioned most often by smokers in all countries and across survey waves as a trigger for thinking about quitting. This is in line with previous studies, which found that cigarette price increases can stimulate smoking cessation and motivation to quit (Brown et al., 2014b; Cavazos-Rehg et al., 2014; Ross et al., 2011). Another study in which respondents were asked how useful they thought different tobacco control policies are revealed that reimbursement for smoking cessation medication was much higher rated than price increases or the extension of smoking bans (Ferketich et al., 2014). The differences between this study and our study may be explained by the fact that this study measured how useful the general population thought the policies were, while our study measured whether policies triggered smokers to think about quitting.

The first research question was whether self-reported triggers for thinking about quitting would change over time. With respect to cigarette price, an increase in reporting of this trigger was seen in The Netherlands and France. This was in accordance with actual price increases corrected for inflation in The Netherlands. There were increases in mentioning this as a trigger between 2008 
Table 3

GEE analyses ${ }^{\mathrm{a}}$ showing associations of time (wave), education, and income with four triggers for thinking about quitting for six countries (weighted data).

\begin{tabular}{|c|c|c|c|c|c|c|}
\hline Price of cigarettes & France OR (95\% CI) & Germany OR (95\% CI) & The Netherlands OR $(95 \% \mathrm{CI})$ & Ireland OR (95\% CI) & Scotland OR $(95 \% \mathrm{CI})$ & UK OR $(95 \% \mathrm{CI})$ \\
\hline \multicolumn{7}{|l|}{ Main effects } \\
\hline Wave & $1.24(1.10 \text { to } 1.39)^{-2 *}$ & $0.91(0.82$ to 1.00$)$ & $1.13(1.08 \text { to } 1.18)^{* *}$ & $0.96(0.70$ to 1.31$)$ & $0.89(0.68$ to 1.18$)$ & $1.01(0.98$ to 1.04$)$ \\
\hline \multicolumn{7}{|l|}{ Education } \\
\hline High & 1.00 & 1.00 & 1.00 & 1.00 & 1.00 & 1.00 \\
\hline Moderate & $1.12(0.95$ to 1.33$)$ & $1.63(1.28 \text { to } 2.06)^{* *}$ & $1.04(0.89$ to 1.21$)$ & $0.82(0.61$ to 1.09$)$ & $2.10(1.28 \text { to } 3.44)^{*}$ & $1.15(1.00$ to 1.31$)$ \\
\hline Low & $1.28(1.02$ to 1.62$)$ & 1.35 (1.02 to 1.77$)$ & $0.95(0.80$ to 1.13$)$ & $0.96(0.70$ to 1.30$)$ & $1.92(1.14$ to 3.25$)$ & $1.03(0.89$ to 1.18$)$ \\
\hline \multicolumn{7}{|l|}{ Income } \\
\hline High & 1.00 & 1.00 & 1.00 & 1.00 & 1.00 & 1.00 \\
\hline Moderate & $1.20(1.03$ to 1.40$)$ & $1.33(1.07$ to 1.65$)$ & $1.21(1.05 \text { to } 1.40)^{*}$ & $1.03(0.81$ to 1.31$)$ & $2.20(1.31 \text { to } 3.70)^{*}$ & $1.08(0.96$ to 1.21$)$ \\
\hline Low & $1.45(1.22 \text { to } 1.72)^{* * *}$ & $1.69(1.34 \text { to } 2.14)^{* *}$ & $1.41(1.21 \text { to } 1.63)^{* *}$ & $1.23(0.94$ to 1.60$)$ & $1.72(0.97$ to 3.04$)$ & 1.20 (1.04 to 1.38$)$ \\
\hline \multicolumn{7}{|l|}{ Interaction effects (separate analyses) } \\
\hline Education $\times$ wave & $p=0.064$ & $p=0.367$ & $p=0.559$ & $p=0.339$ & $p=0.095$ & $p=0.004$ \\
\hline Income $\times$ wave & $p=0.562$ & $p=0.272$ & $p=0.088$ & $p=0.460$ & $p=0.420$ & $p=0.454$ \\
\hline Smoking restrictions & France OR $(95 \% \mathrm{Cl})$ & Germany OR (95\% CI) & The Netherlands OR (95\% CI) & Ireland OR (95\% CI) & Scotland OR $(95 \% \mathrm{CI})$ & UK OR $(95 \% \mathrm{CI})$ \\
\hline \multicolumn{7}{|l|}{ Main effects } \\
\hline Wave & $0.72(0.63 \text { to } 0.81)^{* *}$ & $0.72(0.65 \text { to } 0.81)^{* *}$ & $0.92(0.88 \text { to } 0.96)^{* *}$ & $0.83(0.64$ to 1.08$)$ & $0.66(0.50 \text { to } 0.88)^{*}$ & $1.14(1.11 \text { to } 1.17)^{* *}$ \\
\hline \multicolumn{7}{|l|}{ Education } \\
\hline High & 1.00 & 1.00 & 1.00 & 1.00 & 1.00 & 1.00 \\
\hline Moderate & $1.16(0.98$ to 1.37$)$ & 1.20 (0.97 to 1.48$)$ & $0.95(0.82$ to 1.11$)$ & $0.95(0.75$ to 1.21$)$ & $1.09(0.73$ to 1.62$)$ & $1.06(0.94$ to 1.20$)$ \\
\hline Low & $1.28(1.02$ to 1.60$)$ & $1.43(1.11 \text { to } 1.84)^{\circ}$ & $1.08(0.90$ to 1.29$)$ & $0.94(0.73$ to 1.22$)$ & $1.27(0.80$ to 2.01$)$ & $1.05(0.93$ to 1.19$)$ \\
\hline \multicolumn{7}{|l|}{ Income } \\
\hline High & 1.00 & 1.00 & 1.00 & 1.00 & 1.00 & 1.00 \\
\hline Moderate & $1.38(1.18 \text { to } 1.62)^{* * *}$ & $1.25(1.00$ to 1.56$)$ & $0.98(0.84$ to 1.15$)$ & $1.25(1.02$ to 1.54$)$ & $1.59(0.94$ to 2.68$)$ & $0.91(0.81$ to 1.01$)$ \\
\hline Low & $1.39(1.17 \text { to } 1.65)^{n * *}$ & $1.25(1.00$ to 1.56$)$ & $1.04(0.88$ to 1.23$)$ & $1.06(0.84$ to 1.32$)$ & $1.33(0.76$ to 2.33$)$ & $0.99(0.88$ to 1.13$)$ \\
\hline \multicolumn{7}{|l|}{ Interaction effects (separate analyses) ${ }^{b}$} \\
\hline Education $\times$ wave & $p=0.021$ & $p=0.055$ & $p=0.049$ & $p=0.434$ & $p=0.009$ & $p=0.540$ \\
\hline Income $\times$ wave & $p=0.079$ & $p=0.568$ & $p=0.644$ & $p=0.025$ & $p=0.009$ & $p=0.006$ \\
\hline Free or lower cost medication & France OR $(95 \% \mathrm{Cl})$ & Germany OR (95\% CI) & The Netherlands OR (95\% CI) & Ireland OR (95\% CI) & Scotland OR $(95 \% \mathrm{CI})$ & UK OR $(95 \% \mathrm{CI})$ \\
\hline \multicolumn{7}{|l|}{ Main effects } \\
\hline Wave & Not measured & $0.98(0.86$ to 1.11$)$ & $0.98(0.94$ to 1.02$)$ & $1.02(0.79$ to 1.32$)$ & $0.84(0.62$ to 1.13$)$ & $1.03(1.00$ to 1.05$)$ \\
\hline \multicolumn{7}{|l|}{ Education } \\
\hline High & & 1.00 & 1.00 & 1.00 & 1.00 & 1.00 \\
\hline Moderate & & $1.98(1.52 \text { to } 2.57)^{* *}$ & $1.33(1.13 \text { to } 1.56)^{* *}$ & $1.12(0.88$ to 1.43$)$ & $1.52(1.01$ to 2.29$)$ & $1.10(0.97$ to 1.24$)$ \\
\hline & & $2.21(1.63 \text { to } 3.00)^{* *}$ & 1.21 (1.01 to 1.46$)$ & $1.34(1.04$ to 1.72$)$ & $1.77(1.10$ to 2.86$)$ & $1.13(1.00$ to 1.29$)$ \\
\hline \multicolumn{7}{|c|}{$2.21(1.63$ to 3.00$)$} \\
\hline High & & 1.00 & 1.00 & 1.00 & 1.00 & 1.00 \\
\hline Moderate & & $1.53(1.14 \text { to } 2.04)^{\circ}$ & $1.02(0.87$ to 1.20$)$ & $1.17(0.94$ to 1.47$)$ & $1.77(1.03$ to 3.04$)$ & $1.13(1.01$ to 1.26$)$ \\
\hline Low & & 1.50 (1.12 to 2.00$)^{*}$ & $1.32(1.13 \text { to } 1.56)^{* *}$ & $1.57(1.24 \text { to } 1.98)^{* * *}$ & $1.40(0.77$ to 2.54$)$ & $1.22(1.08 \text { to } 1.39)^{*}$ \\
\hline \multicolumn{7}{|l|}{ Interaction effects (separate analyses) ${ }^{\mathrm{b}}$} \\
\hline Education $\times$ wave & & $p=0.216$ & $p=0.184$ & $p=0.672$ & $p=0.563$ & $p=0.149$ \\
\hline Income $\times$ wave & & $p=0.811$ & $p=0.395$ & $p=0.110$ & $p=0.193$ & $p=0.254$ \\
\hline Warning labels on cigarette packs & France OR $(95 \% \mathrm{CI})$ & Germany OR $(95 \% \mathrm{CI})$ & The Netherlands OR $(95 \% \mathrm{Cl})$ & Ireland OR $(95 \% \mathrm{CI})$ & Scotland OR $(95 \% \mathrm{CI})$ & UK OR $(95 \% \mathrm{CI})$ \\
\hline \multicolumn{7}{|l|}{ Main effects } \\
\hline Wave & $1.11(0.99$ to 1.23$)$ & $0.94(0.85$ to 1.04$)$ & $0.96(0.91$ to 1.01$)$ & $0.77(0.59$ to 1.01$)$ & $1.07(0.79$ to 1.44$)$ & $0.95(0.93 \text { to } 0.98)^{* * *}$ \\
\hline \multicolumn{7}{|l|}{ Education } \\
\hline High & 1.00 & 1.00 & 1.00 & 1.00 & 1.00 & 1.00 \\
\hline Moderate & $1.22(1.03$ to 1.44$)$ & 1.25 (0.98 to 1.59$)$ & $1.13(0.92$ to 1.39$)$ & $1.15(0.90$ to 1.46$)$ & $1.38(0.91$ to 2.11$)$ & $0.96(0.84$ to 1.09$)$ \\
\hline \multirow{2}{*}{\multicolumn{7}{|c|}{$2.16(1.36 \text { to } 3.43)^{*}$}} \\
\hline & & & & & & \\
\hline High & 1.00 & 1.00 & 1.00 & 1.00 & 1.00 & 1.00 \\
\hline Moderate & $1.24(1.07 \text { to } 1.43)^{\circ}$ & $1.20(0.96$ to 1.50$)$ & $1.26(1.03$ to 1.56$)$ & $1.21(0.99$ to 1.49$)$ & $1.09(0.63$ to 1.88$)$ & $1.00(0.89$ to 1.12$)$ \\
\hline Low & $1.41(1.20 \text { to } 1.66)^{* *}$ & $1.32(1.06$ to 1.65$)$ & $1.62(1.31 \text { to } 2.01)^{* *}$ & $1.54(1.23 \text { to } 1.93)^{* *}$ & $1.29(0.71$ to 2.32$)$ & $1.18(1.04$ to 1.35$)$ \\
\hline \multicolumn{7}{|c|}{ Interaction effects (separate analyses) } \\
\hline Education $\times$ wave & $p=0.007$ & $p=0.557$ & $p=0.029$ & $p=0.460$ & $p=0.199$ & $p=0.356$ \\
\hline Income $\times$ wave & $p=0.199$ & $p=0.282$ & $p=0.380$ & $p=0.034$ & $p=0.149$ & $p=0.432$ \\
\hline
\end{tabular}

a All analyses were adjusted for sex, age, HSI, and time in sample.

b $p$-Values for overall tests of model effects ${ }^{*} p<0.01,{ }^{* *} p<0.001$. 
and 2009 after a price increase in 2008, and the same was found between 2010 and 2011. In France, there was an increase between 2008 and 2012, although no large price increases were implemented. In total, half of the cigarette price increases were followed by a significant increase in smokers mentioning cigarette price as a trigger for thinking about quitting.

In contrast, with regard to smoking restrictions in public places, the implementation was followed by a decrease in mentioning this as a trigger for thinking about quitting in four countries. We found a general increase in mentioning this trigger in the UK, but this increase took place before the implementation of the smoking restrictions in 2007. However, previous research showed that smoking restrictions are effective in stimulating smoking cessation (Wilson et al., 2012). Therefore, a probable explanation for our finding is that smokers quit smoking in anticipation of the actual implementation of the smoking restrictions as previous research showed as well (Fowkes et al., 2008).

With respect to warning labels on cigarette packs, we saw an increase between 2008 and 2012 in mentioning this as a trigger for thinking about quitting in France which is likely to be related to the introduction of pictorial warning labels in France between April, 2010 and April, 2011. We also found a decrease between 2003 and 2004 in the UK where text warning labels were implemented in 2003 before the (wave 2) survey measurement. Furthermore, mentioning warning labels increased between October, 2008 and the second half of 2010 in the UK where pictorial warning labels were introduced between October, 2008 and September, 2010. This is consistent with previous research showing that implementing textual as well as pictorial warning labels is associated with changes in self-reported indicators of impact (European Commission, 2009; Hammond et al., 2004). Taking the results together, we found partial support for our expectation that smokers would be more likely to mention recently implemented policies as a trigger for thinking about quitting. We saw more expected increases (29\%) than unexpected increases (14\%).

The second research question was whether there were education and income differences regarding these policy triggers for thinking about quitting. It is notable that all policies were mentioned more often by low and/or moderate education smokers than high education smokers and by low and/or moderate income smokers than high income smokers. Education differences were especially large for free or lower cost medication and for warning labels, while income differences were especially large for price of cigarettes and free or lower cost medication. Most previous studies that investigated socioeconomic differences in reporting reasons to quit also described that groups with a low SES mentioned economic costs more often than smokers with a high SES (Gallus et al., 2013; Hill et al., 2014; Pisinger et al., 2011; Vangeli and West, 2008). Previous studies on socioeconomic differences in the impact of free or lower cost medication and warning labels showed mixed results (Brown et al., 2014a; Giskes et al., 2007; Hitchman et al., 2012; Vangeli and West, 2008; Yong et al., 2014).

For the third research question we examined whether the education and income differences changed over time. We saw that for most policies and in most countries, the associations did not change significantly over time. The largest change was that low education smokers in France mentioned warning labels more often over time than moderate and high education smokers. Because pictorial warning labels were introduced in 2010, this suggests that these warning labels might function more often as a trigger among low education smokers.

\subsection{Practical implications}

The results of the present study showed that low SES smokers perceive changes in policies more often as a trigger for thinking about quitting than high SES smokers. However, previous research indicated that low SES smokers are less likely to quit smoking (Hiscock et al., 2012). Future public health campaigns, which often accompany new policies, should therefore be targeted at low SES smokers to support them in their quitting. Previous research showed mixed results regarding the effect of such campaigns for different socioeconomic subgroups, but emphasized the importance of sufficient exposure and campaign reach for low SES groups (Durkin et al., 2012). With these campaigns, low SES smokers could be well informed about the introduction of new policies and reminded that this is a good opportunity to make a quit attempt.

\subsection{Limitations}

Several limitations should be taken into account when interpreting the results. First of all, the survey waves were not always conducted immediately before and after a change in policy which would have made the interpretation of the relationships between policy implementation and thinking about quitting more straightforward. Another limitation is that the measures used in this study were self-reported perceptions of impact. Smokers' perceptions of what triggered them to think about quitting may differ from actual triggers. We also only investigated policy triggers for thinking about quitting among continuing smokers, i.e., those who did not quit due to the policy implementation. Because such triggers could actually influence cessation behavior, we have most likely underestimated the importance of policy triggers after the actual policy implementation. Moreover, a considerable number of respondents were lost to follow-up. Because young smokers were more likely to drop out of the sample in all countries, the results of the current study may not be fully generalizable to all smokers. Furthermore, the included countries conducted different numbers of survey waves, with a different number of participants, and different time intervals between survey waves which impedes the interpretation of country differences. Nevertheless, most findings were comparable across countries.

\subsection{Conclusion}

Tobacco control policies have the potential to work as a trigger to increase thoughts about quitting in smokers with low education and low income. The four policies examined in this study (cigarette price, smoking restrictions in public places, free or lower cost medication, and warning labels) were mentioned more often as triggers for thinking about quitting by low/moderate education and low/moderate income smokers than high education and high income smokers. The education and income differences did not change significantly over time for most policies and in most countries. Our findings about self-reported perceptions of impact suggest that tobacco control policies have the potential to reduce health inequalities in smoking.

\section{Role of funding source}

The ITC Europe surveys were supported by grants from the French Institute for Health Promotion and Health Education (INPES), the French National Cancer Institute (INCa), Observatoire Français des drogues et toxicomanies (OFDT) (06/2d0708/191-2-LL) (France), The Netherlands Organization for Health Research and Development (ZonMw) (121010008, 70000001, 200130002) (The Netherlands), German Federal Ministry of Health, Dieter Mennekes-Umweltstiftung, German Cancer Research Center (DKFZ) (Germany), US National Cancer Institute R01 CA090955 (Ireland), Cancer Research UK C312/A6465, Cancer Research UK C312/A3726, Cancer Research UK C312/A11039 (UK), NHS Health Scotland RE065, and Flight Attendants' Medical 
Research Institute (FAMRI) (Scotland). The ITC Project is supported by the US National Cancer Institute (P50 CA111236, R01 CA100362, and P01 CA138389), and the Canadian Institutes of Health Research $(57897,79551,115016)$. Additional support was provided to Geoffrey T. Fong from a Senior Investigator Award from the Ontario Institute for Cancer Research and a Prevention Scientist Award from the Canadian Cancer Society Research Institute. This paper is a deliverable within the SILNE Project 'Tackling socioeconomic inequalities in smoking: Learning from natural experiments by time trend analyses and cross-national comparisons'. The SILNE Project is funded by the European Commission through FP7 HEALTH-F3-2011-278273.

The funders had no involvement in the design of the study, the collection, analysis and interpretation of the data, the writing of the paper, or the decision to submit the paper for publication.

\section{Contributors}

$\mathrm{KH}$ conducted the statistical analyses and drafted the manuscript. She is the guarantor of the paper. GEN and HdV contributed to the design of the study. All authors contributed to the interpretation of the data and to the writing of the manuscript. All authors revised the manuscript critically for important intellectual content and read and approved the final manuscript.

\section{Conflict of interest statement}

No conflict declared.

\section{Acknowledgements}

Several members of the ITC Project team at the University of Waterloo have assisted in all stages of conducting the ITC Europe surveys, which we gratefully acknowledge. In particular, we thank Thomas Agar, Project Manager of ITC Europe, and Frank Chaloupka, who advised on the price data and inflation correction.

\section{References}

Baha, M., Le Faou, A.L., 2010. Smokers' reasons for quitting in an anti-smoking social context. Public Health 124, 225-231, http://dx.doi.org/10.1016/j.puhe. 2010.02.011

Ballinger, G.A., 2004. Using generalized estimating equations for longitudinal data analysis. Organ. Res. Methods 7, 127-150.

Bandura, A., 1986. Social Foundations of Thought and Action: A Social Cognitive Theory. Prentice-Hall, Englewood Cliffs, NJ.

Brown, T., Platt, S., Amos, A., 2014a. Equity impact of European individual-level smoking cessation interventions to reduce smoking in adults: a systematic review. Eur. J. Public Health 24, 551-556, http://dx.doi.org/10.1093/eurpub/ cku065

Brown, T., Platt, S., Amos, A., 2014b. Equity impact of population-level interventions and policies to reduce smoking in adults: a systematic review. Drug Alcohol Depend. 138, 7-16, http://dx.doi.org/10.1016/j.drugalcdep.2014 03.001

Caleyachetty, A., Lewis, S., McNeill, A., Leonardi-Bee, J., 2012. Struggling to make ends meet: exploring pathways to understand why smokers in financial difficulties are less likely to quit successfully. Eur. J. Public Health 22 (Suppl. 1), 41-48, http://dx.doi.org/10.1093/eurpub/ckr199

Cavazos-Rehg, P.A., Krauss, M.J., Spitznagel, E.L., Chaloupka, F.J., Luke, D.A., Waterman, B., Grucza, R.A., Bierut, L.J., 2014. Differential effects of cigarette price changes on adult smoking behaviours. Tob. Control 23, 113-118, http:// dx.doi.org/10.1136/tobaccocontrol-2012-050517

Driezen, P., Thompson, M.E., 2011. Comparing Policy Measures Across Multiple ITC Countries: Adjusting for Time-in-Sample. University of Waterloo.

Durkin, S., Brennan, E., Wakefield, M., 2012. Mass media campaigns to promote smoking cessation among adults: an integrative review. Tob. Control 21 (2), 127-138, http://dx.doi.org/10.1136/tobaccocontrol-2011-050345

European Commission, 2009. Survey on tobacco: analytical report. In: Flash Eurobarometer. European Commission, pp. 253.

European Commission, 2014. Manufactured Tobacco: Excise Duty Rates. European Commission, From 〈https://circabc.europa.eu/faces/jsp/extension/wai/ navigation/container.jsp $\rangle$

Ferketich, A.K., Lugo, A., La Vecchia, C., Fernandez, E., Boffetta, P., Clancy, L., Gallus, S., 2014. Relation between national-level tobacco control policies and individual-level voluntary home smoking bans in Europe. Tob. Control, http:// dx.doi.org/10.1136/tobaccocontrol-2014-051819

Fishbein, M., Ajzen, I., 2010. Predicting and Changing Behavior: The Reasoned Action Approach. Taylor \& Francis, New York, NY.

Fong, G.T., Cummings, K.M., Borland, R., Hastings, G., Hyland, A., Giovino, G.A., Hammond, D., Thompson, M.E., 2006. The conceptual framework of the International Tobacco Control (ITC) Policy Evaluation Project. Tob. Control 15 (Suppl. 3), 3-11, http://dx.doi.org/10.1136/tc.2005.015438

Fowkes, F.J., Stewart, M.C., Fowkes, F.G., Amos, A., Price, J.F., 2008. Scottish smoke-free legislation and trends in smoking cessation. Addiction 103 , 1888-1895, http://dx.doi.org/10.1111/j.1360-0443.2008.02350.x

Gallus, S., Muttarak, R., Franchi, M., Pacifici, R., Colombo, P., Boffetta, P., Leon, M.E., La Vecchia, C., 2013. Why do smokers quit? Eur. J. Cancer Prev. 22, 96-101, http://dx.doi.org/10.1097/CEJ.0b013e3283552da8

Giskes, K., Kunst, A.E., Ariza, C., Benach, J., Borrell, C., Helmert, U., Judge, K., Lahelma, E., Moussa, K., Ostergren, P.O., Patja, K., Platt, S., et al., 2007. Applying an equity lens to tobacco-control policies and their uptake in six Western-European countries. J. Public Health Policy 28, 261-280, http://dx.doi. org/10.1057/palgrave.jphp.3200132

Giskes, K., Kunst, A.E., Benach, J., Borrell, C., Costa, G., Dahl, E., Dalstra, J.A., Federico, B., Helmert, U., Judge, K., Lahelma, E., Moussa, K., 2005. Trends in smoking behaviour between 1985 and 2000 in nine European countries by education. J. Epidemiol. Community Health 59, 395-401, http://dx.doi.org/10.1136/jech. 2004.025684

Grotvedt, L., Stavem, K., 2005. Association between age, gender and reasons for smoking cessation. Scand. J. Public Health 33, 72-76, http://dx.doi.org/10. 1080/14034940410028361

Guillaumier, A., Bonevski, B., Paul, C., D’Este, C., Doran, C., Siahpush, M., 2014 Paying the price: a cross-sectional survey of Australian socioeconomically disadvantaged smokers' responses to hypothetical cigarette price rises. Drug Alcohol Rev. 33, 177-185, http://dx.doi.org/10.1111/dar.12103

Hammond, D., McDonald, P.W., Fong, G.T., Brown, K.S., Cameron, R., 2004. The impact of cigarette warning labels and smoke-free bylaws on smoking cessation: evidence from former smokers. Can. J. Public Health 95, 201-204.

Harper, S., Lynch, J., 2007. Trends in socioeconomic inequalities in adult health behaviors among U.S. states, 1990-2004. Public Health Rep. 122, 177-189.

Heatherton, T.F., Kozlowski, L.T., Frecker, R.C., Rickert, W., Robinson, J., 1989. Measuring the heaviness of smoking: using self-reported time to the first cigarette of the day and number of cigarettes smoked per day. Br. J. Addict. 84, 791-799.

Hill, S., Amos, A., Clifford, D., Platt, S., 2014. Impact of tobacco control interventions on socioeconomic inequalities in smoking: review of the evidence. Tob. Control 23 (e2), e89-e97, http://dx.doi.org/10.1136/tobaccocontrol-2013-051110

Hiscock, R., Bauld, L., Amos, A., Fidler, J.A., Munafo, M., 2012a. Socioeconomic status and smoking: a review. Ann. N.Y. Acad. Sci. 1248, 107-123, http://dx.doi.org/ 10.1111/j.1749-6632.2011.06202.x

Hiscock, R., Bauld, L., Amos, A., Platt, S., 2012b. Smoking and socioeconomic status in England: the rise of the never smoker and the disadvantaged smoker. Public Health (Oxford) 34, 390-396, http://dx.doi.org/10.1093/pubmed/fds012

Hitchman, S.C., Mons, U., Nagelhout, G.E., Guignard, R., McNeill, A., Willemsen, M.C., Driezen, P., Wilquin, J.L., Beck, F., Du-Roscoat, E., Potschke-Langer, M. Hammond, D., Fong, G.T., 2012. Effectiveness of the European Union text-only cigarette health warnings: findings from four countries. Eur. J. Public Health 22, 693-699, http://dx.doi.org/10.1093/eurpub/ckr099

Hosseinpoor, A.R., Bergen, N., Kunst, A., Harper, S., Guthold, R., Rekve, D., d'Espaignet, E.T., aidoo, N., Chatterji, S., 2012. Socioeconomic inequalities in risk factors for non communicable diseases in low-income and middle-income countries: results from the World Health Survey. BMC Public Health 12, 912, http://dx.doi.org/10.1186/1471-2458-12-912

Jin, J.M., 2011. Working Correlation Selection in Generalized Estimating Equations. University of Iowa (Ph.D. Dissertation)

Kaleta, D., Korytkowski, P., Makowiec-Dabrowska, T., Usidame, B., Bak-Romaniszyn, L., Fronczak, A., 2012. Predictors of long-term smoking cessation: results from the global adult tobacco survey in Poland (2009-2010). BMC Public Health 12, 1020, http://dx.doi.org/10.1186/1471-2458-12-1020

Lang, T.A., Secic, M., 2006. How to Report Statistics in Medicine, second ed. American College of Physicians, Philadelphia, PA.

McCaul, K.D., Hockemeyer, J.R., Johnson, R.J., Zetocha, K., Quinlan, K., Glasgow, R.E., 2006. Motivation to quit using cigarettes: a review. Addict. Behav. 31, 42-56, http://dx.doi.org/10.1016/j.addbeh.2005.04.004

Pisinger, C., Aadahl, M., Toft, U., Jorgensen, T., 2011. Motives to quit smoking and reasons to relapse differ by socioeconomic status. Prev. Med. 52, 48-52, http:// dx.doi.org/10.1016/j.ypmed.2010.10.007

Rogers, R.W., Prentice-Dunn, S., 1997. Protection motivation theory. In: Gochman, D.S. (Ed.), Handbook Of Health Behavior Research I: Personal And Social Determinants. Plenum Press, New York, NY.

Rosenstock, I., 1974. Historical origins of the health belief model. Health Educ. Behav. 2, 328-335.

Ross, H., Blecher, E., Yan, L., Hyland, A., 2011. Do cigarette prices motivate smokers to quit? New evidence from the ITC survey. Addiction 106, 609-619, http://dx. doi.org/10.1111/j.1360-0443.2010.03192.x

Scollo, M., Hayes, L., Wakefield, M., 2013. What price quitting? The price of cigarettes at which smokers say they would seriously consider trying to quit. BMC Public Health 13, 650, http://dx.doi.org/10.1186/1471-2458-13-650 
The International Tobacco Control Evaluation Project, 2014. Methods. The International Tobacco Control Evaluation Project, Retrieved 04.06.2015, from 〈www.itcproject.org .

The World Bank, 2015. Consumer Price Index. The World Bank, from 〈http://data.worldbank.org/indicator/FP.CPI.TOTL〉.

Thompson, M.E., Fong, G.T., Hammond, D., Boudreau, C., Driezen, P., Hyland, A., Borland, R., Cummings, K.M., Hasting, G.B., Siahpush, M., Mackintosh, A.M., Laux, F.L., 2006. Methods of the International Tobacco Control (ITC) Four Country Survey. Tob. Control 15 (Suppl. 3), 12-18, http://dx.doi.org/10.1136/tc. 2005.013870

Vangeli, E., West, R., 2008. Sociodemographic differences in triggers to quit smoking: findings from a national survey. Tob. Control 17, 410-415, http://dx. doi.org/10.1136/tc.2008.025650
WHO, 2003. Framework Convention on Tobacco Control. World Health Organization, Geneva.

WHO, 2012. WHO Global Report: Mortality Attributable to Tobacco. World Health Organization, Geneva.

Wilson, L.M., Avila Tang, E., Chander, G., Hutton, H.E., Odelola, O.A., Elf, J.L.,

Heckman-Stoddard, B.M., Bass, E.B., Little, E.A., Haberl, E.B., Apelberg, B.J., 2012 Impact of tobacco control interventions on smoking initiation, cessation, and prevalence: a systematic review. J. Environ. Public Health 2012, 961724, http:/ dx.doi.org/10.1155/2012/961724

Yong, H.H., Borland, R., Thrasher, J.F., Thompson, M.E., Nagelhout, G.E., Fong, G.T., Hammond, D., Cummings, K.M., 2014. Mediational pathways of the impact of cigarette warning labels on quit attempts. Health Psychol. 33, 1410-1420, http://dx.doi.org/10.1037/hea0000056. 